\title{
わが国のトランスレーショナルリサーチ/ 臨床試験の現状と課題
}

浜松医科大学医学部臨床薬理学・臨床薬理内科渡邊裕司

\section{はじめに}

translational research (TR) は動物実験を含む 基礎研究の成果をはじめて人を対象とした臨床試 験につなげるステップであり，それに続く各相の 臨床試験とともに新しい医療技術や医薬品の開発 に欠かすことができない. しかし，これまで日本 では TR/臨床試験の素地が十分でなく, 内資系製 薬企業であっても TR/臨床試験を海外で実施す ることが多い状況にあった. 事実, コアジャーナ ルに掲載される臨床研究論文数の国際比較では, わが国の順位は低下の一途をたどっており，さら に掲載された論文を撤回するという残念な事態も 生じている.このような危機的状況を打開するた めには, TR/臨床試験の意義を再確認し, 被験者 保護およびデー夕の信頼性確保という基本に立ち 戻るとともに，TR/臨床試験が円滑に進むような 体制整備が必要となる。 2015年 4 月からは臨床 研究に関する新たな倫理指針として「人を対象と する医学系研究の倫理指針」 ${ }^{1)}$ が施行され, さら にこれまでの文部科学省 (文科省), 厚生労働省 (厚労省), 経済産業省など各省庁からの縦割りの ファンディングの弊害をなくし，一元的な予算管 理のもとに臨床研究を推進し医療イノベーション を実現することを目的として日本医療研究開発機 構 2 が発足した.

日本の治験に新 GCP が適用されるようになつ
た1998年, 日本の治験環境には大きな変革がもた らされた。 その状況と類似して, 日本の TR/臨 床試験はいま大きな転換点を迎えている. 本項で は, わが国の循環器領域における TR/臨床試験 の状況について概括したい.

\section{$T R /$ 臨床試験の必要性}

国立大学法人は平成 28 年度からの 6 年間, 第三 期中期目標・計画に沿つて大学を運営し事業展開 することとなる。この目標設定に先立ち平成 26 年 9 月 9 日, 文科省高等教育局国立大学法人支援課 長から事務連絡として以下に示す「国立大学法人 の組織及び業務全般の見直しに関する視点」が公 表された。

『附属病院は, 優れた医療人を養成するととも に, 質の高い臨床研究を行う教育研究機関である との基本的な認識を踏まえつつ, 卒前教育と卒後 教育の一体的な魅力ある教育プログラムの構築 や, 新たな医薬品・医療技術等の研究開発に取り 組むことが必要ではないか. また地域の医療需要 を踏まえて, 高度急性期医療機能の強化を図るな ぞ, 都道府県等と連携して地域医療に取り組むこ とが必要ではないか. これらの取組を通じて特色 ある病院運営の強化を図ることが必要ではない か.』

今後 6 年間の国立大学法人附属病院のミッショ 
ンとして, 臨床研究に関する教育の強化と, 新た な医薬品・医療技術などの研究開発の重要性が強 く打ち出されていることに注目したい.

医学研究の倫理原則に照らしても, 臨床試験を 通じた新たな医薬品・医療技術の創出はわれわれ のミッションと考えられる。臨床研究の倫理原則 を示したベルモントレポートでは, 被験者の人格 の尊重, 善行, 正義という 3 つの要素があげられ ている.このなかの正義の実践には, 前提として その臨床試験を実施することに科学的, 医学的な 意義があり, 期待される成果が医学知識の増大と 医学の進歩に結びつくものであることが求められ ており, さらにここで強調されるは, 臨床試験か ら得られるべネフィットがリスクとともに社会に 公平公正に分配されることである. 現在われわれ が享受している医療は, 過去に実施された臨床試 験の成果によりもたらされており，世代間でもべ ネフィットとリスクの公平公正な分配の原則は適 用されると考えれば，将来の患者に対し私たちは よりよい医療を創り伝えていく義務を負つている ことになる ${ }^{3)}$.

また，日本が置かれた医療経済的状況という観 点からも，TR/臨床試験を通じた新たな医薬品や 医療技術創出が喫緊の課題となっている. 現在, 日本の医師数は約 32 万人, 薬剤師数は約 30 万人 であり，30年前に比べるとそれぞれ約1.7倍, 約 3 倍に増加している. 医学部が定員数を増やし, 薬 系の学部や大学も増加した現在の状況を考える と, 医師数, 薬剤師数は今後も増え続けることが 予測される. 一方, 日本の人口は2004年にピーク に達したのち, 減少に転じ, 将来も減り続けると 予想されている.さらに深刻なのは稼ぎ手である 生産年齢人口割合が減少し続けることである.こ のような日本の人口や人口構成比の変化を考慮す ると, 医療費が現在のように確保されるかは極め て不透明と思われる. 医師, 薬剤師, 看護師など の医療職は，医療費の分配に預かり生活の糧を得 ているわけだが，今後は減少するかもしれない医 療費を, より多くの人数で配分しなければならな くなるかもしれない.このような状況を打開する
ためには, 医療イノベーションを現実のものと し, 医療が社会的利益とともに経済的利益をもた らすような構造に転換する必要があるのではない だろうか. 現在の日本の医療は, 既存の医薬品や 医療機器を患者にどのように使用するかに重きが 置かれた消費型医療といって過言ではなく，そこ で使用される医薬品・医療機器の多くは輸入製品 であり多額の貿易赤字を生んでいる。 このような 状況から脱却し, 医師自らが医薬品や医療機器の 開発に携わり, 日本発の医療が世界の患者に貢献 し，もってその利益が日本に還元されるような開 発・輸出型の医療構造に転換することが, 上記の 問題を解決するための大きな力となると思われ る. 日本の医療を将来も質高く維持するために も, TR/臨床試験の推進が極めて重要となる.

\section{TR/臨床試験を活性化させるための 日本の取り組み}

ゲノム創薬や遺伝情報に基づく個別化治療の発 展など, 創薬をめぐる環境の変化を踏まえつつ, 新たな医薬品・医療機器の開発を促進するため, 文部科学省と厚生労働省は2003年に全国治験活 性化 3 か年計画を発表した。この計画では, ス ピード, 質, コストといつた面での日本の治験の 課題への取り組みや治験コーディネーター等治験 関係スタッフの人材養成などが図られた。 その 後, 治験の活性化や実施体制整備については, 2007年からの「新たな治験活性化 5 か年経過」, 2012年からの「臨床研究・治験活性化 5 力年計画 $2012\rfloor^{4)} に 引 き$ 継がれ，この間に医師主導治験や先 進医療の制度が整備されてきた（図 1)。さらに文 部科学省は 2007 年, 5 年間のプロジェクトとして 橋渡し研究支援推進プログラムを開始し, 2012 年からは引き続き橋渡し研究加速ネットワーク プログラム ${ }^{5)}$ を実施している. 同様に厚生労働省 は2011年より早期・探索的臨床試験拠点整備事 業6), 2012年よりは臨床研究中核病院整備事業 ${ }^{7)}$ ならびにグローバル臨床研究拠点整備事業を実施 している. 臨床研究中核病院整備事業（図 2) 
図 1 革新的医薬品を創出する 流れ
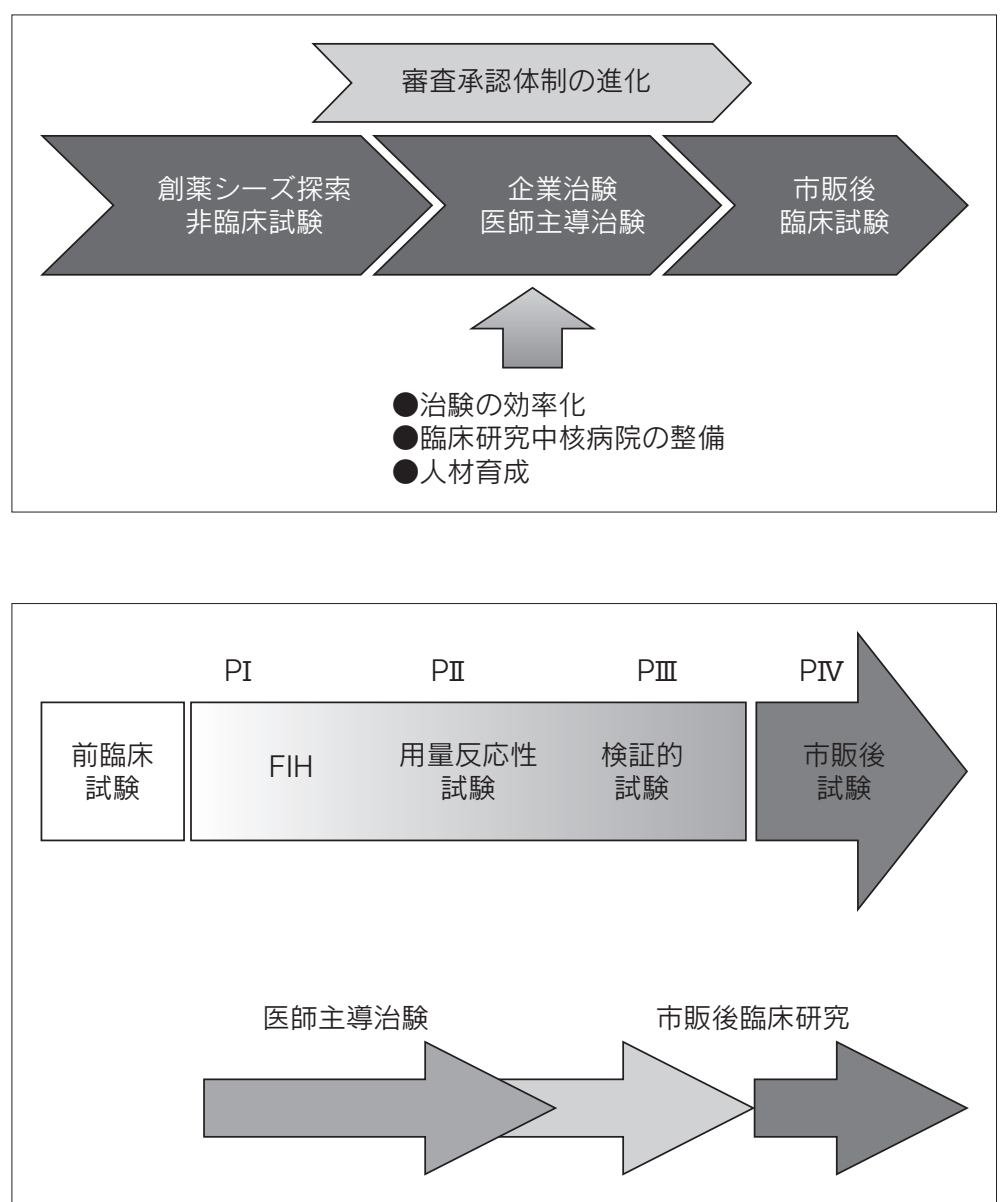

図 2 臨床研究中核病院整備事業 (2012年〜)
は, 日本発の革新的な医薬品・医療機器の創出な ぞを目的に，国際水準の臨床研究，難病などの医 師主導治験および市販後臨床研究などの中心的役 割を担う臨床研究中核病院を整備する事業であ り, 早期 - 探索的臨床試験拠点と合わせ 15 の病院 が選ばれている。

このような体制整備とともに制度上も，革新的 医薬品・医療機器・再生医療などの製品を日本で 早期に実用化することを目的として，その開発を 促進するために，厚生労働省は「先駆け審査指定 制度」を創設してその試行的運用を開始してい る。この制度は，世界に先駆けて医薬品などの実 用化を図るため, わが国の大学, 研究機関などの 基礎研究の成果を迅速に実用化につなげるよう, 医薬品などの研究・開発から臨床試験・治験, 承
認審査, 保険適用, 国際展開までの対策を, 厚生 労働省関係部局が連携し, 一体となつて取り組む ため設けられたものである.これには，世界に先 駆けて日本で開発され，早期の治験段階で著明な 有効性が見达まれる革新的な医薬品について，優 先審査し, 早期の承認を目指す「先駆け審査指定 制度」と，これまでドラッグ・ラグ解消のため, 欧米で既承認の薬を国内企業に開発要請してきた が, 今後は既承認薬だけでなく, 欧米で未承認の 薬まで拡大することで，国内での実用化を加速す る「未承認薬迅速実用化スキーム」などの施策が 盛り込まれている.

さらに2015年 4 月には, 医療分野の研究開発に おける基礎から実用化までの一貫した研究開発の 推進 ・成果の円滑な実用化および医療分野の研究 


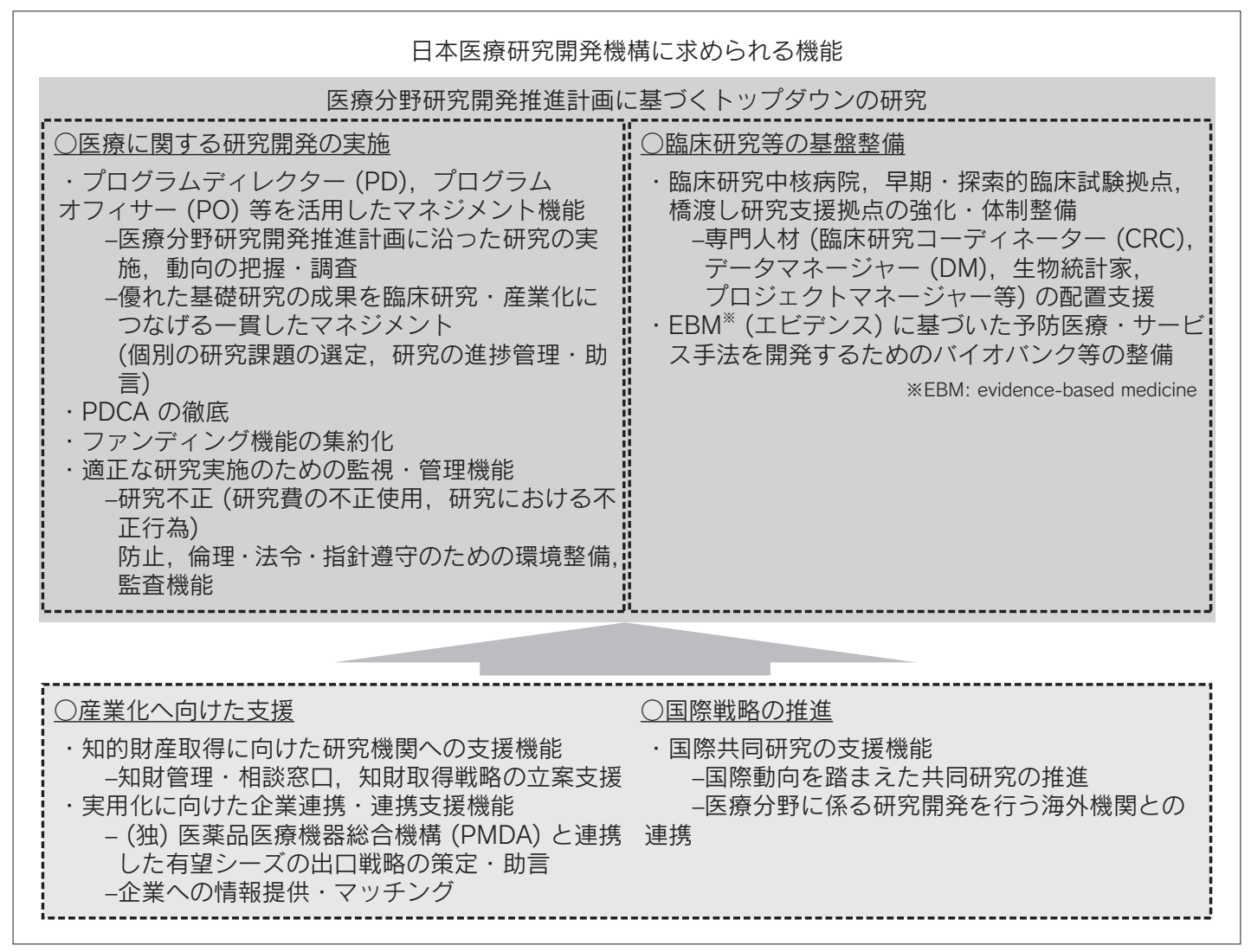

図 3

開発のための環境の整備を総合的かつ効果的に行 うため日本医療研究開発機構 (AMED) が誕生し $た^{2)}$ (図 3). AMED は, わが国の医療分野の研究 開発およびその環境整備の中核的な役割を担う機 関となり，これまで文部科学省・厚生労働省・経 済産業省に計上されてきた医療分野の研究開発に 関する予算を集約し，再生医療，がんなど主に 9 つの医療分野（表 1）において基礎段階から実用 化まで一貫した研究のマネジメントを行い，成果 を円滑に国民に還元することを目的としている. このような取り組みにより，わが国において TR/ 臨床試験を実施する体制は，人材養成とともに確 実に整備されてきた。
表 1 (独) 日本医療研究開発機構における省連携の 9 プロジェクト

1. オールジャパンでの医薬品創出

2. オールジャパンでの医療機器開発

3. 革新的医療技術創出拠点プロジェクト

4. 再生医療の実現化ハイウェイ構想

5. 疾病克服に向けたゲノム医療実現化プロジェクト

6. ジャパン・キャンサーリサーチプロジェクト

7. 脳とこころの健康大国実現プロジェクト

8. 新興 · 再興感染症制御プロジェクト

9. 難病克服プロジェクト

\section{今後の課題}

近年，日本の製薬企業で創出されたシーズが減 少しつつあることが報告されているが，その持つ 意味は深刻である. どのように日本での TR/臨床 
試験環境が整備されたとしても, 肝心のシーズが 枯渴してしまえば，その意義は失われてしまう。 日本発の新薬候補創出をどのように増やしていく かには, 日本の研究開発投資のあり方, 研究開発 税制のあり方, 教育・研究制度の改革といった多 方面の政策アプローチが必要である ${ }^{81}$.また，こ のような状況でこそ, アカデミア発のシーズ探索 と, それを臨床の場へトランスレーションする早 期探索的な医師主導治験の役割は重要となる. 本 来, 医師主導治験は, 採算性などの問題で企業が 開発に着手しない場合であっても，医師，歯科医 師自らが治験届を提出して臨床デー夕を収集する ことで医薬品の承認を図ろうとするものであった が, 最近では先進医療によっても, 未承認の医薬 品・医療機器を用いて評価療養の制度下で研究的 診療（臨床試験）が可能となつている. 日本の限 られたリソースを最大限効率的に活用するために は, アカデミアで発見・開発されたシーズを臨床 に供するためのトランスレーショナルリサーチを 医師主導治験の真の対象とすべきだろう。同時 に,「日本で実施された臨床試験の結果を世界が 信頼する」という環境を整備するためには，何よ りも臨床試験にかかわる医師をはじめとした人材 教育が必要となる. 欧米では臨床研究を通じてエ ビデンスを構築し, 新たな医療を創っていくこと が医療者の責務であるという意識が浸透してい る. 一方, 日本では, 臨床試験の意義を理解する 医療者は決して多くなく, さらに薬事承認目指し た医薬品開発計画に精通した医師は極めて少な い.これらの背景が, わが国の TR/ 臨床試験を 脆弱化させる要因となっている. 医薬品臨床開発 の質を向上させるためには, 今後この分野の医師
の卒前・卒後教育が必須の課題となろう。これら のハードルを乗り越えることで, 日本から世界へ 良質のエビデンスを発信し，世界の患者に貢献す る役割を日本が担う，そのような基盤が整備され ることを期待したい。

著者の COI (conflicts of interest) 開示: 本論文発表 内容に関連して特に申告なし

\section{文献}

1) 人を対象とする医学系研究に関する倫理指針 (平成 26 年 文部科学省・厚生労働省告示第 3 号 http://www.mext.go.jp/b_menu/houdou/26/12/_ icsFiles/afieldfile/2014/12/22/1354186_1.pdf

2) 国立研究開発法人日本医療研究開発機構ホームページ http://www.amed.go.jp/

3) 渡邊裕司：治験と倫理. GCP ハンドブック第 5 版 医 薬品の臨床試験の実施の基準，渡邊裕司編，じほう， 東京, 2014, 3-9.

4）文部科学省・厚生労働省ホームページ 臨床研究・治験 活性化 5 力年計画 2012 http://www.mhlw.go.jp/topics/bukyoku/isei/chiken/ d1/120403_3.pdf

5）文部科学省橋渡し研究加速ネットワークプログラム ホームページ http://www.tr.mext.go.jp/

6) 厚生労働省ホームページ早期・探索的臨床試験拠点整 備事

http://www.mhlw.go.jp/stf/houdou/2r9852000001jym4. $\mathrm{html}$

7) 厚生労働省ホームページ臨床研究中核病院整備事 http://www.mhlw.go.jp/stf/shingi/2r9852000002th21. html

8) 厚生労働科学研究費補助金 医薬品・医療機器等レギュ ラトリーサイエンス総合研究事業「医師主導治験の運 用に関する研究」平成 23 年度総括・分担研究報告書: 研究代表者 渡邊裕司 